\title{
RE-EXPOSURE OF HUMAN LYMPHOBLASTOID CELL LINES TO EPSTEIN-BARR VIRUS
}

\author{
by

\begin{abstract}
Volker Diehl ${ }^{\mathbf{1}}$, Hans Wolf ${ }^{2}$, Heinrich Schulte-Holthausen ${ }^{2}$ and Harald zur Hausen ${ }^{2}$
Institut für Virologie der Universität, 8700 Würzburg, Versbacher Landstr. 7, West Germany
\end{abstract}

Human lymphoblastoid lines of various origins which harbour Epstein-Barr virus $(E B V)$-specific nucleic acid were re-exposed to EBV. Following infection, cells of the non-virus-producing lines, Raji and $S 95$, predominantly synthesized $E B V$-specific early antigens (EA), whereas only a small percentage of cells revealed viral capsid antigens (VCA). In Raji cells, the number of VCA-producing cells was paralleled by the percentage of virus-specific DNA-synthesizing cells. In $S 95$ cells, however, viral DNA-synthesizing cells exceeded the number of VCA-producing cells by a factor of more than 10. Induction of EA in Raji cells was dose-dependent and inversely related to cell growth. Irradiation of the virus by ultraviolet light prior to infection led to reduced infectivity. This reduction seemed to follow single-hit kinetics. Raji cells, previously re-exposed to $E B V$, showed reduced $E A$ induction after re-infection with $E B V$, as compared to Raji control cells not previously exposed. Of 10 lines which spontaneously synthesize $E B V$-specific antigens, seven lines proved to be refractory to re-infection, whereas three were as susceptible as the Raji and $S 95$ controls. From three of the refractory lines infectious virus could be recovered from the culture medium prior to infection.

These results permit the following interpretations: (1) the response of human lymphoblastoid cells after re-infection with EBV results from the infecting virus and not from stimulation of endogenous genomes; (2) cells demonstrating $E A$ synthesis ultimately die; (3) re-exposure to $E B V$ increases the resistance to re-infection of the surviving cells; and (4) cell lines producing infectious $E B V$ are refractory to re-infection. It is suggested that the spontaneous synthesis of infectious virus favours the selection of resistant cells.

Epstein-Barr virus (EBV) specific antigens have been observed in all human lymphoblastoid cell lines which were carefully examined for their presence (reviewed by Epstein, 1970; Klein, 1972; zur Hausen, 1972). Usually a small number of cells synthesize EBV, whereby the rate of virus production seems to be cell-line-specific. Cloning experiments (Zajac and Kohn, 1970; Maurer et al., 1970), induction of viral particle synthesis by chemical inducers (Hampar et al., 1972; Gerber, 1972), and nucleic acid hybridization experiments (zur Hausen and Schulte-Holthausen, 1970; Nonoyama and Pagano, 1971; zur Hausen et al., $1972 b$ ) revealed that every one of these cells carries the viral genetic information. There exists also some evidence that uptake of viral genomes is a prerequisite for their continuous proliferation in tissue culture (Pope et al., 1968; Nilsson et al., 1971; Chang et al., 1971). Transformation of human lymphocytes in vitro is quite easily achieved by infecting these cells with EBV (Henle et al., 1967; Pope et al., 1968; Chang et al., 1971).

Received: May 10, 1972.

1 Present Address: Abteilung für Onkologie-Hämatologie, Medizinische Hochschule Hannover, 3000 Hanover-Kleefeld, Roderbruchstr. 101, West Germany.

${ }^{2}$ Present address: Institut für klinische Virologie, 852, Erlangen, Loschgestr. 7, West Germany. 
Despite a number of efforts, however, EBV cannot be grown in primary human or animal cells. Neither epithelial nor fibroblastic cells proved to be susceptible for this agent and attempts to produce virus in primary human leukocytes were also unsuccessful. Since a relationship of this virus to infectious mononucleosis has been postulated (Henle et al., 1968; Niederman et al., 1968), still undiscovered permissive cells (permissive for virus production) must exist in order to guarantee the continuous transfer of viral infections.

In recent years it has been shown that some lymphoblastoid cell lines of human origin which already harbour EB viral genomes (reviewed by zur Hausen, 1972) are susceptible to re-infection by EBV (Horosciewicz et al., 1970; Durr et al., 1970; Pearson et al., 1970). These cells, although probably previously transformed by the same virus, represent at the present time the only subject for studying the time course of EB viral macromolecule synthesis in lytic infections. Most of these cells become abortively infected: they synthesize EBV-specific antigens without viral particle production (Henle et al., 1970; Henle et al., 1971). The susceptibility of cells from lymphoblastoid lines to re-infection varies from line to line. This seems to depend in part on the presence or absence of virus-specific receptors on the cell membrane (Klein et al., personal communication).
The following report tries to analyze some of the aspects of re-infection of selected lymphoblastoid cell lines by EBV. Special attention is focused on the question whether the alterations of the host cells, induced upon re-exposure, are due to stimulation of endogenous or to newly penetrated viral genomes. The synthesis of viral DNA in the abortive cycle, as well as the reinfectibility of EBV-synthesizing cells, in comparison to cells of non-virus-producing lymphoblastoid lines, are also examined.

\section{MATERIAL AND METHODS}

\section{Cell lines}

The origin of cell lines used in these experiments is summarized in Table I. The Table also contains the percentage of cells which reveal EBVspecified antigens as detected by immunofiuorescence. The cells were maintained in medium RPMI 1629 supplemented with 10 or $20 \%$ foetal bovine serum, penicillin and streptomycin (Diehl et al., 1968).

\section{EBV preparations}

EBV was obtained from P3HR-1 cells by two procedures: (1) $700 \mathrm{ml}$ of supernatants from P3HR-1 cells $\left(1.5-2.2 \times 10^{6}\right.$ cells $\left./ \mathrm{ml}\right)$, grown for $10-12$ days at $34^{\circ} \mathrm{C}$, were clarified by low-speed centrifugation $(10 \mathrm{~min}, 1,000 \times \mathrm{g})$. This was followed by centrifugation at $45,000 \times g$ over a

TABLE I

ORIGIN OF CELL LINES AND PRESENCE OF EBV-SPECIFIC ANTIGENS WITHIN THEIR CELLS

\begin{tabular}{|c|c|c|c|c|}
\hline \multirow{2}{*}{ Cell line } & \multirow{2}{*}{ Origin } & \multirow{2}{*}{ References } & \multicolumn{2}{|c|}{$\begin{array}{l}\text { EBV-reactivity percent } \\
\text { fluorescent cells }\end{array}$} \\
\hline & & & EA and VCA & VCA \\
\hline P3HR-1 & Burkitt's lymphoma-clone of P3J & Hinuma et al. (1967) & $7.5 \%$ & $4.5 \%$ \\
\hline HK LY-28 & 3 Nasopharyngeal carcinoma (tumor) & de Thé et al. (1969) & $1.6 \%$ & $0.4 \%$ \\
\hline Kaplan & Infect. mononucleosis (per. blood) & Diehl et al. (1968) & 1.75 & $0.6 \%$ \\
\hline Di I & Healthy individual (per. blood) & Diehl, unpublished results & $10.7 \%$ & $9.6 \%$ \\
\hline Di II & Healthy individual (per, blood) & Diehl, unpublished results & $1.8 \%$ & $0.5 \%$ \\
\hline Di IV & Healthy individual (per. blood) & Diehl, unpublished results & $0.6 \%$ & $0.4 \%$ \\
\hline Di V & Healthy individual (per. blood) & Diehl, unpublished results & $0.6 \%$ & $0.4 \%$ \\
\hline Raji & Burkitt's lymphoma (tumor) & Pulvertaft (1964) & $<0.001 \%$ & $<0.001 \%$ \\
\hline S-95 & $\begin{array}{l}\text { Hodgkin's disease, sarcoma type } \\
\text { (pleural effusion) }\end{array}$ & $\begin{array}{l}\text { Diehl and Johansson, in } \\
\text { preparation }\end{array}$ & $<0.001 \%$ & $<0.001 \%$ \\
\hline S118 & $\begin{array}{l}\text { Hodgkin's disease, granul. type } \\
\text { (per. blood) }\end{array}$ & $\begin{array}{l}\text { Diehl and Johansson, in } \\
\text { preparation }\end{array}$ & $0.5 \%$ & $0.1 \%$ \\
\hline $2003\left(P_{3} J\right)$ & Burkitt's lymphoma (tumor) & Pulvertaft, unpublished results & $0.1 \%$ & $0.1 \%$ \\
\hline SHO I & Healthy individual (per. blood) & Diehl, unpublished results & $4.5 \%$ & $2.5 \%$ \\
\hline
\end{tabular}


period of $110 \mathrm{~min}$ in the 21 rotor of the Beckman preparative centrifuge. The resulting sediment was resuspended in a small volume in order to obtain a 30- to 70-fold concentrate. The pH of these preparations was adjusted to 7.0. They were stored at $4^{\circ} \mathrm{C}$ until used. Concentrates could be kept at this temperature up to 17 days without detectable loss of infectious EBV. (2) Supernatants of P3HR-1 cells, kept for 6-8 days in the same medium, were clarified by two centrifugations at $1,000 \times g$ for $10 \mathrm{~min}$ each. The supernatants were carefully removed with a Pasteur pipette, their pH was adjusted and they were stored at $4^{\circ} \mathrm{C}$ until used.

In addition to P3HR-1 cells, concentration of EBV was attempted from five other EBVproducing cell lines (Di-I, Di-II, Kaplan, HK LY-28, S118). Supernatants from a non-virusproducing line (Raji) were concentrated in the same way and used as controls.

\section{Infectivity tests}

Infectivity was assayed by infecting $3 \times 10^{6}$ cells with $1 \mathrm{ml}$ of the virus suspension. The virus was allowed to absorb for $2 \mathrm{~h}$ at $37^{\circ} \mathrm{C}$. Thereafter, $8 \mathrm{ml}$ of fresh culture medium were added. After additional incubation for 48 and $72 \mathrm{~h}$ at $37^{\circ} \mathrm{C}$, the cells were acetone-fixed and examined for EBV-specific antigen production by direct immunofluorescence.

\section{Immunofluorescence tests}

Infected cells were monitored for induction of EBV-associated capsid (VCA) and early antigens (EA) by methods described by Henle et al. (Henle and Henle, 1966; Henle et al., 1970). For VCA tests, fluorescein-isothiocyanate (FITC) conjugated human serum (anti-VCA titre $1: 640$ ), derived from a healthy individual, was used in a dilution of $1: 30$. At this concentration no reactivity against $\mathrm{EA}$ could be detected.

A FITC-conjugated serum from a patient with Burkitt's lymphoma "Nathan" was kindly supplied by Dr. George Klein (Karolinska Institutet, Stockholm), and used for the detection of EA in a dilution of $1: 20-30$. The difference in fluorescence-positive cells, resulting from the separate incubation of infected cells with both sera, indicated the EA reactivity.

\section{Cell counting}

The number of viable cells was determined by trypan-blue exclusion tests in the Neubauer haematocytometer chamber.

\section{Irradiation of EBV by ultraviolet light (UV)}

Five $\mathrm{ml}$ of the virus suspension (in RPMI 1629 with $10 \%$ calf serum in a $6 \mathrm{~cm}$ Petri dish) were UV-irradiated (Thomas UV-lamp) at a distance of $10 \mathrm{~cm}$ for different periods of time, during which they were continuously stirred with a magnetic stirrer.

\section{Membrane and in situ hybridizations}

The techniques used for membrane and in situ hybridizations have been described before (zur Hausen and Schulte-Holthausen, 1970; zur Hausen and Schulte-Holthausen, 1972a). EBVspecific complementary RNA (cRNA), of high specific radioactivity (about $2 \times 10^{7} \mathrm{cpm} / \mu \mathrm{g}$ ) synthesized in vitro with the aid of $E$. coli RNA polymerase, was used for all tests.

\section{RESULTS}

Induction of EBV-associated antigens and virusspecific DNA synthesis in Raji and $S 95$ cells

After infection of Raji cells with concentrated EBV, derived from P3HR-1 supernatants, the time course of virus-specific macromolecule synthesis was studied. After various periods post infection, cells were removed for immunofluorescence and in situ hybridizations. In addition, DNA was extracted for filter hybridization with EBV-cRNA. The results are shown in Figure 1.

EBV-specific early antigens appeared first about $12 \mathrm{~h}$ after infection, as previously described by others (Henle et al., 1970; Gergely et al., 1971; Horosciewicz et al., 1970). The number of fluorescent cells increased up to $72 \mathrm{~h}$ PI. Thereafter it rapidly declined, and only an occasional cell was still found to be positive for EA 30 days after infection. VCA was first detected about $24 \mathrm{~h}$ after exposure to EBV but only in a small number of cells $(1.5 \%)$. After 6 additional days no VCA synthesis was discernible.

The number of VCA-synthesizing cells was paralleled by the counts of labelled nuclei after in situ hybridizations. Thus, EBV-DNA synthesis after re-infection of Raji cells was correlated to VCA production. Additional confirmation for 


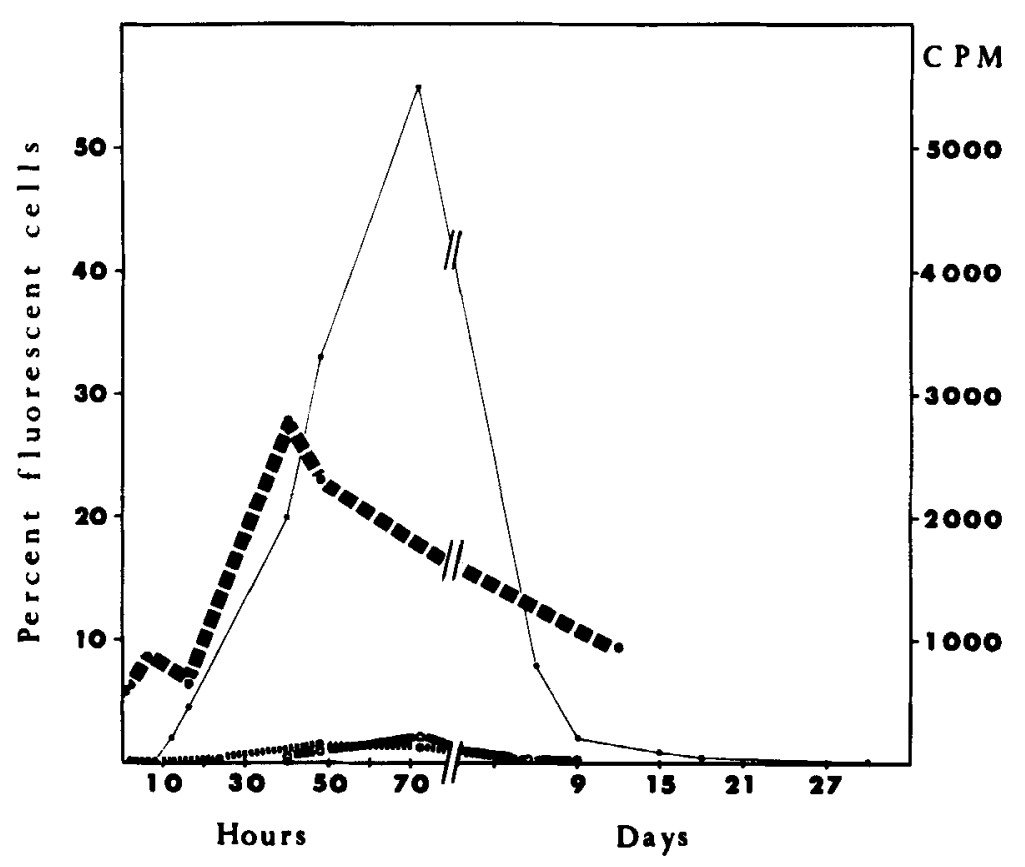

Figure 1

Induction of EBV-specific antigens and viral DNA synthesis after infection of Raji cells with EBV. Early antigen synthesis (-—) starts after about $12 \mathrm{~h}$ and reaches a peak about $72 \mathrm{~h}$ post infection. Only a small number of cells demonstrate VCA production (.........). Approximately the same number of cells synthesize viral DNA (O $O$ ), as shown by in situ hybridization with EBV-cRNA. A significant increase of virus-specific DNA synthesis after infection with EBV is also indicated by hybridization on nitrocellulose filters of DNA derived from infected cells after various periods of infection with EBV-cRNA ( $\cdot \mathbf{m} \mathbf{m} \cdot)$.

virus-specific DNA synthesis originated from membrane hybridizations. Hybridizability of Raji DNA with EBV-cRNA increased approximately 15 -fold about $40 \mathrm{~h}$ post infection.

In $\mathbf{S} 95$ cells, infection with EBV concentrates provoked a similar response as far as EA and VCA synthesis were concerned (Fig. 2). The decline in EA synthesis after 3 days PI, however, was slower than in Raji cells. Despite a low percentage of VCA-synthesizing cells $(1.8 \%$ $48 \mathrm{~h}$ after infection), there was a surprisingly high number of EBV-DNA producing cells as revealed by in situ hybridizations (Fig. 3). Three days after infection they exceeded the counts for VCA-positive cells 22-fold, approaching the number of EA-reactive cells. This increased EBV-DNA production in $\mathrm{S} 95$ cells as compared to Raji cells was also indicated by an approximately 30-fold increase in hybridization with
EBV-cRNA $40 \mathrm{~h}$ after infection as compared to values of uninfected $S 95$ cells. The discrepancy in the number of VCA-producing and EBV DNA-synthesizing cells after EBV-re-infection was repeatedly observed in this line and remains as yet unexplained.

Dose-response after re-exposure of Raji and $S 95$ cells to $E B V$

Induction of EBV-specified antigens (EA and VCA), as well as survival of the infected cells, was studied in Raji and $\mathbf{S} 95$ cells by the use of different dilutions of EBV concentrates for infection. The result is shown in Table II.

This Table demonstrates that EBV antigen reactivity was inversely related to cell survival. When non-diluted viral concentrates were used as input, only a fraction of the original cell population was still alive $72 \mathrm{~h}$ after infection. 


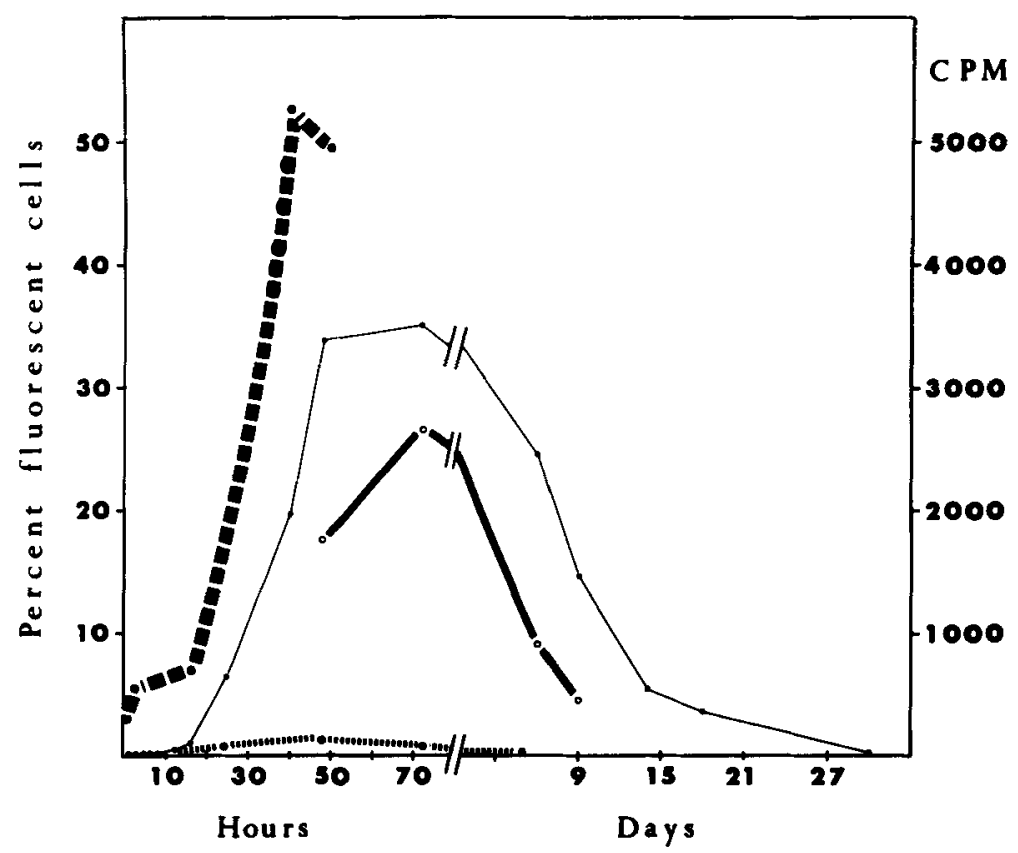

FIGURE 2

Induction of EBV-specific antigens and viral DNA synthesis after infection of $\mathbf{S} 95$ cells with EBV. The increase in early antigen synthesis (-_) is paralleled by an increase in viral DNA synthesis, as revealed by in situ hybridizations $(O)$ ) and hybridization on nitrocellulose filters $(\cdot \mathbf{v a} \cdot)$. Only a small number of cells produce EBV-VCA (........).

This indicated that the abortive infection of Raji and $S 95$ cells resulted in killing of the cells. Apparently induction of early antigens without viral DNA synthesis (at least in the case of Raji cells) led to cell destruction and death.

Although the data shown in Table II did not reveal a linear decrease in the number of fluorescent cells after infection with various dilutions of EBV-concentrates, they indicated the dependence of virus-specific antigen synthesis on the multiplicity of infection. A similar dependence on the EBV-input for virus-specific antigen synthesis and cell survival, as indicated in Table II, has been observed 48 and $96 \mathrm{~h}$ after infection.

$E B V$-specific antigens after infection of Raji cells with UV-irradiated virus

Raji cells were exposed to EBV, irradiated for various periods prior to infection. A representative experiment is shown in Figure 4.
UV-irradiation reduced the number of viral antigen-synthesizing cells corresponding to the time of exposure. Whereas $28.5 \%$ of the cells showed viral antigens $72 \mathrm{~h}$ after infection with non-irradiated virus, almost no specific fluorescence was detectable after $8 \mathrm{~min}$ of irradiation prior to infection. Here again cell survival was inversely related to the dose of infectious virus. The decrease in the induction of virus-specific immunofluorescence after UV-irradiation of the virus seems to follow single-hit kinetics.

\section{Re-exposure of EBV re-infected cells to $E B V$}

To determine whether Raji cells surviving infection with EBV-concentrates remain susceptible to EBV, these cells were re-exposed to the virus 33 and 75 days after the first infection. Uninfected Raji cells served as controls. The result is shown in Figure 5. 


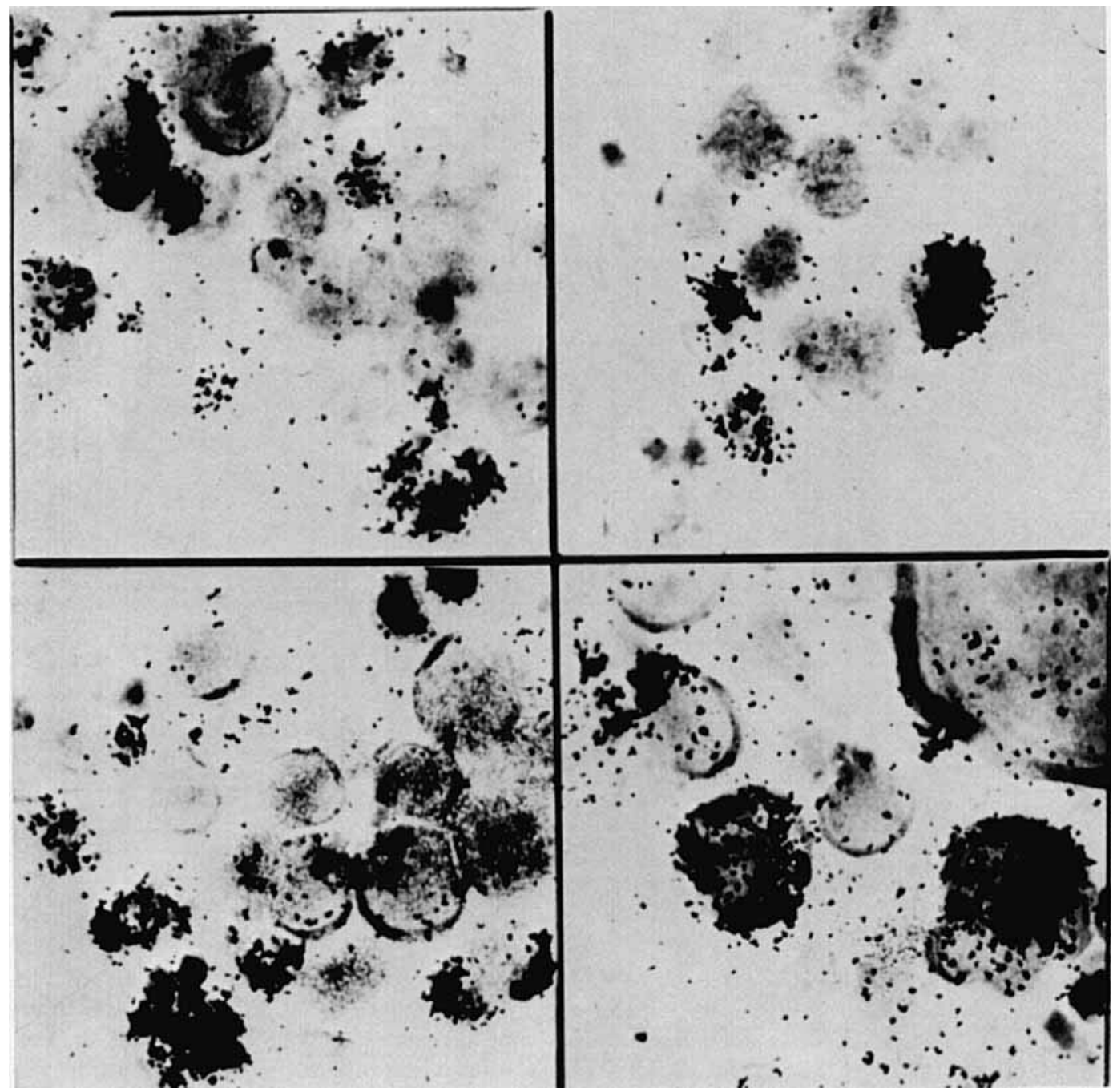

\section{Figure 3}

In situ hybridization of ${ }^{3} \mathrm{H}$-labelled EBV-cRNA with $\mathrm{S} 95$ cells $72 \mathrm{~h}$ after infection with EBV. Note the heavily labelled nuclei in contrast to some almost unlabelled cells.

The pre-infected Raji cells were less susceptible to re-infection. This was especially pronounced in the Raji line which had been infected 75 days earlier.

By annealing DNA from both pre-exposed Raji lines with EBV-cRNA, these hybridized slightly above the values of DNA from noninfected Raji cells (1.32 and 1.38 times more than the controls). This could suggest that exposure of Raji cells to EBV increased the viral genome content of the surviving cells.
Re-infection of cells from $E B$ virus-synthesizing lines with $E B V$

Cells of EBV-synthesizing lymphoblastoid lines were infected with EBV concentrates. Raji and S 95 cells served as controls. Figure 6 shows the EA and VCA synthesis in five recently isolated virus-synthesizing lines after infection with $\mathrm{EBV}$. Four of these lines (Di-II, Di-IV, Di-V, and SHO, all derived from healthy donors) did not show any increase in virus-specific antigen 
TABLE II

INDUCTION OF EBV-ASSOCIATED ANTIGENS $72 \mathrm{H}$ AFTER INFECTION OF RAJI AND $S 95$ CELLS WITH VARIOUS CONCENTRATIONS OF EBV

\begin{tabular}{clcc}
\hline Cell line & $\begin{array}{c}\text { Dilution of } \\
\text { EBV-concentrate }\end{array}$ & $\begin{array}{c}\text { \% EA and } \\
\text { VCA reactive } \\
\text { cells } 72 \text { h PI }\end{array}$ & $\begin{array}{c}\text { Number of } \\
\text { surviving } \\
\text { cells/ml } \\
\mathbf{7 2} \text { h PI } \times 10^{\circ}\end{array}$ \\
\cline { 1 - 3 } Raji & non-dil. & 45 & 0.05 \\
$"$, & $1: 3$ & 36 & 0.14 \\
$"$ & $1: 9$ & 14 & 0.29 \\
$"$ & $1: 27$ & 10 & 0.65 \\
S 95 & no virus & 0 & 1.31 \\
$"$ & non-dil. & 25 & 0.10 \\
$"$ & $1: 3$ & 21 & 0.21 \\
$"$ & $1: 9$ & 9 & 0.25 \\
& $1: 27$ & 6 & 0.34 \\
& no virus & 0 & 0.59 \\
\hline
\end{tabular}

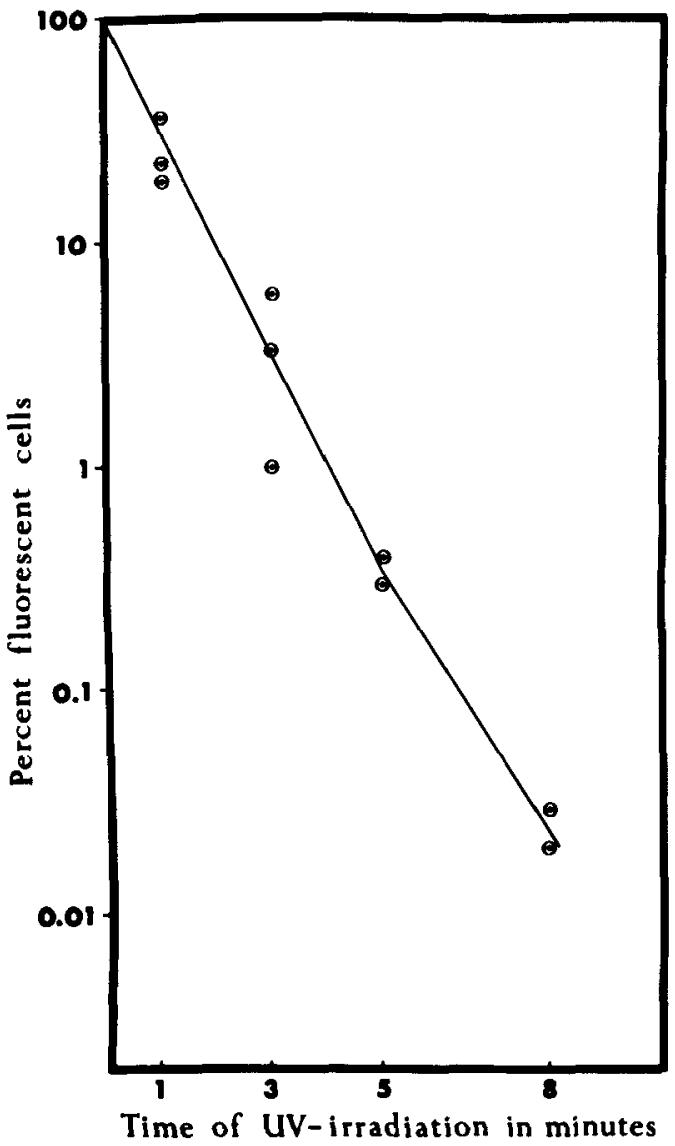

Figure 4

Induction of early antigens in Raji cells after infection with EBV irradiated for various periods by ultraviolet light.

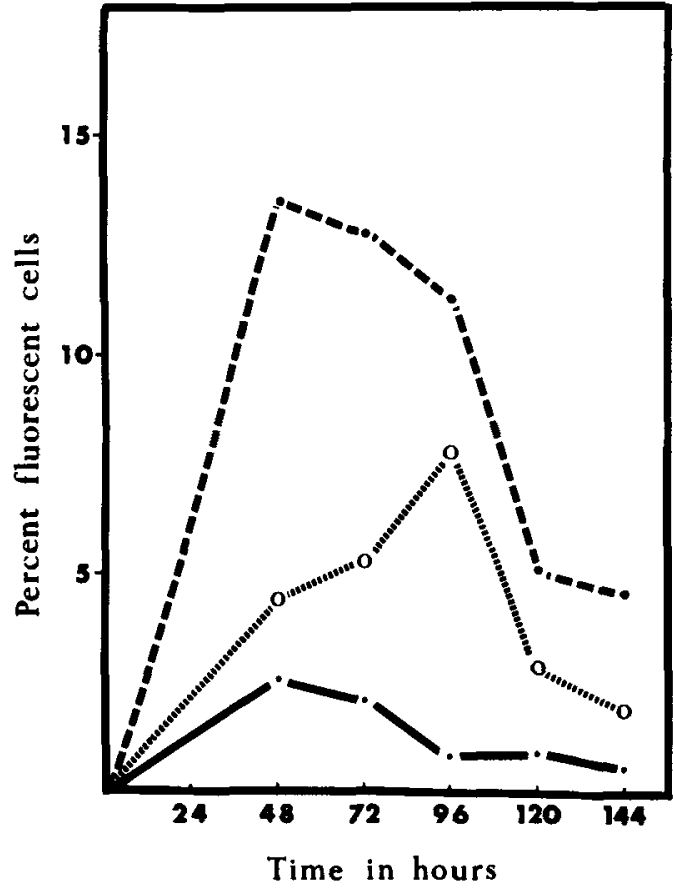

FiguRe 5

Re-exposure of EBV re-infected cells to EBV 33 $(0 \ldots \ldots)$ and 75 days ( exposure to EBV. (-n-) represents the control which was not pre-exposed to EBV.

synthesis. The fifth one, however, S 118 , derived from the peripheral blood of a patient with Hodgkin's disease, was as sensitive to reinfection as Raji and $\mathbf{S} \mathbf{9 5}$ cells.

Following infection of cells of five additional virus-producing lines, most of which had been in culture for several years, three of these (P3HR-1, 2003, and Di-I) proved to be refractory to re-infection (Fig. 7). The other two, Kaplan and HKLY-28, however, showed a considerable increase in early antigen synthesis. To a lesser extent, an increase in viral capsid antigen positive cells was also noted in these two lines.

Recovery of infectious virus from virus-producing cell lines

Supernatants of cells from six EB virus VCAsynthesizing lines were concentrated one hundred fold and used for infection of Raji cells. The 


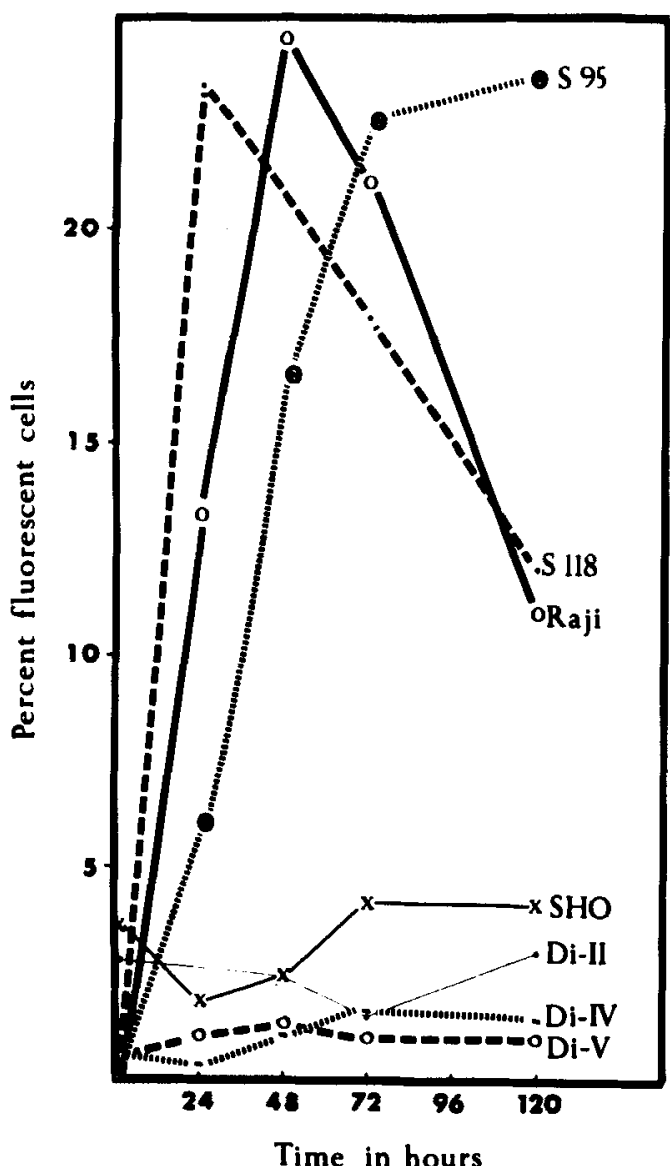

Figure 6

Induction of early antigen synthesis in various cell lines after infection with EBV. Except for the Raji control, all other lines represent recent isolates.

induction of EA in these cells after various periods of infection is shown in Table III. The two lines with a rather high VCA-reactivity (P3HR-1 and Di-I) induced EA synthesis in Raji cells $72 \mathrm{~h}$ post infection in 30.1 and $22.4 \%$ respectively. A third line which was also refractory to re-infection, Di-II, induced virus-specific antigens in a very small percentage of cells. Concentrates derived from the three VCAproducing lines which were susceptible to reinfection (HKLY-28, Kaplan, and S 118), did not induce detectable amounts of EBV-specific antigens after infection of Raji cells.

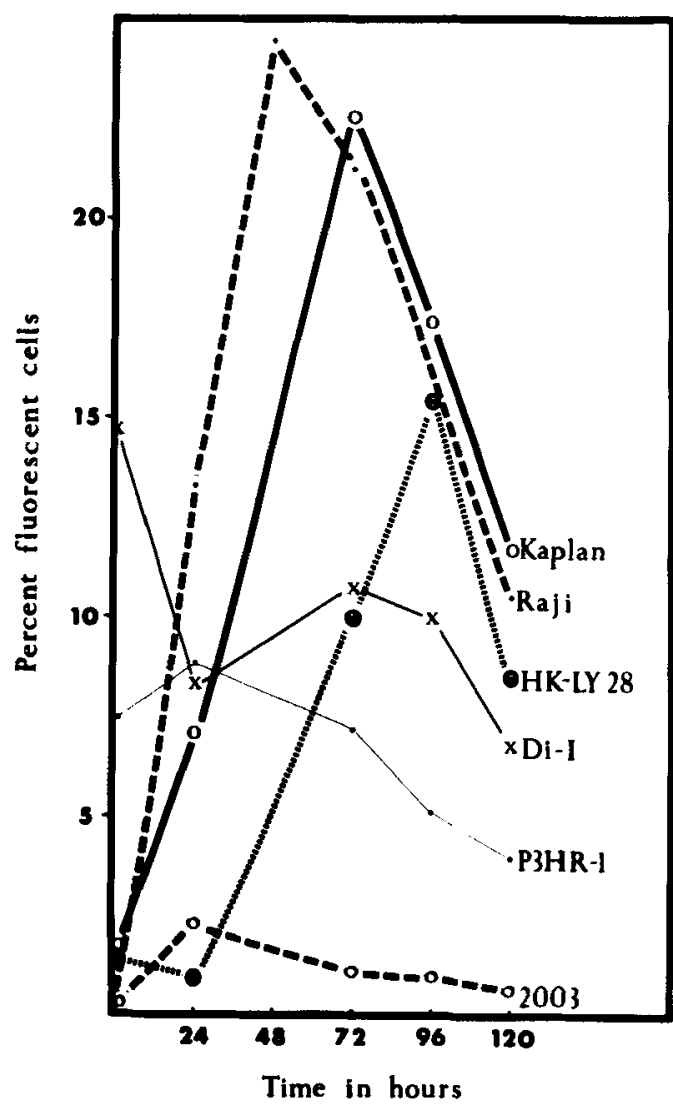

FIGURE 7

Induction of early antigen synthesis, in various cell lines after infection with EBV. Except for the Di-I line, all other lines have been kept in tissue culture for several years.

TABLE III

INFECTION OF RAJI CELLS WITH 100 FOLD CONCENTRATES OF VARIOUS VIRUS PRODUCING CELL LINES

\begin{tabular}{lcccc}
\hline \multirow{2}{*}{$\begin{array}{c}\text { Virus- } \\
\text { donor lines }\end{array}$} & $\begin{array}{c}\text { Percent VCA } \\
\text { reactivity }\end{array}$ & \multicolumn{3}{c}{$\begin{array}{c}\text { Percent VCA and EA positive } \\
\text { cells after }\end{array}$} \\
\cline { 3 - 5 } & $\mathbf{4 8 \mathrm { h }}$ & $72 \mathrm{~h}$ & $\mathbf{9 6 \mathrm { h }}$ \\
\hline HR1K & 5.3 & 29.9 & 30.1 & 19.7 \\
\hline Di-I & 8.4 & 20.2 & 22.4 & 22.1 \\
\hline Di-II & 0.3 & 0.02 & 0.01 & 0 \\
\hline Ly-28 & 0.4 & $0.01(?)$ & 0 & 0 \\
\hline Kaplan & 0.5 & 0 & 0 & 0 \\
\hline S118 & 0.2 & 0 & 0 & 0 \\
\hline
\end{tabular}




\section{DISCUSSION}

Infection of primary human lymphocytes with EBV results in the establishment of lymphoblastoid cell lines (Henle et al., 1967; Diehl et al., 1968; Pope et al., 1968; Nilsson et al., 1971; Miller et al., 1970; Chang et al., 1971). Usually a small percentage of these continuously proliferating cells is induced to synthesize EBV which leads to death of the involved cell. No lytic response, however, has been observed thus far after exposure of primary cells to EBV.

It is therefore rather surprising that cells of several transformed lines which contain a considerable load of persisting EBV genomes (zur Hausen and Schulte-Holthausen, 1970; Nonoyama and Pagano, 1971; zur Hausen and Schulte-Holthausen, 1972b; zur Hausen et al., 1972 ) react upon re-exposure to EBV with virusspecific antigen synthesis and cell death. In this study, the two non-virus-producing lymphoblastoid cell lines, Raji and $\mathbf{S} 95$, proved to be susceptible to re-infection. At least in the majority of the infected cells virus replication was abortive: in Raji cells, early antigen synthesis was predominant. Only a small number of cells revealed viral DNA and VCA production. In S 95 cells, a similar situation was encountered, except for a much higher number of viral DNA-synthesizing cells. Thus far it is not understood why in this case the number of viral structural antigen producing cells, as visualized by immunofluorescence, did not correspond to the number of viral DNA-replicating cells. In both lines, abortive infection resulted in death of the affected cells.

The described reaction of EBV genomecarrying lines to EBV re-infection could be explained by two alternatives: either the infecting genome is responsible for the synthesis of EBVspecific proteins and DNA, or a virus-specific product, transferred to the recipient cell during infection, derepresses and stimulates the endogenous genomes. Our experiments provide evidence for the first alternative, since UVinactivation kinetics point to a direct involvement of the genome of the infecting virus. It is possible that the endogenous EBV genomes in Raji and S 95 cells cannot be reactivated under these conditions due to genomic defects-this in spite of the recent demonstration that Raji cells contain viral DNA of the size of complete genomes (Nonoyama and Pagano, 1972). The reactivation of these genomes after 5-bromodeoxyuridine (BUdR) treatment (Hampar et al., 1972; Gerber, 1972) could be explained by assuming reverting point mutations due to BUdR incorporation.

The response of cells from EBV-synthesizing lines to EBV re-exposure varies from line to line. Whereas seven lines tested in this study proved to be refractory to re-infection, three others were almost as susceptible as the Raji and S95 controls. In these experiments we did not test whether resistance to re-infection, as observed in the majority of virus-synthesizing lines, was due to lack of viral adsorption or to an effect on penetration and uncoating of the virus. It has been shown by Klein et al., 1972 (personal communication), however, that some of the resistant lines do not adsorb virus whereas in others viral adsorption was not inhibited at all.

Since we have been able to isolate infectious virus only from three lines which were resistant to re-infection, these data suggest that resistance to re-infection and infectious virus synthesis might be correlated. It is tempting to speculate that spontaneous induction of infectious virus must result in the selection of cells which are resistant to re-infection with their own virus. The inhibition of the infectious process could occur at various levels before irreparable damage alters the host cell.

This interpretation is supported by the reinfection experiments of Raji cells which survived a previous EBV re-exposure. These cells were more resistant to EBV as compared to the non-exposed control culture.

The abortive response of persistently EBVinfected human lymphoblastoid lines to reinfection, in addition to the non-lytic infection of primary lymphocytes, clearly indicates that the postulated permissive cells which guarantee the continuous transfer of EBV infections, still remain to be discovered.

\section{ACKNOWLEDGEMENTS}

Helpful discussions and the review of this manuscript by Dr. Eberhard Wecker are gratefully acknowledged. We are indebted to Miss Heidi Fuchs for skilful technical assistance.

This work was supported by the "Deutsche Forschungsgemeinschaft ", Bad Godesberg. 


\title{
RÉEXPOSITION DES LIGNÉES CELLULAIRES LYMPHOBLASTOÏDES HUMAINES AU VIRUS D'EPSTEIN-BARR
}

\begin{abstract}
Des lignées lymphoblastoïdes humaines d'origines diverses, qui contiennent de l'acide nucléique spécifique du virus d'Epstein-Barr (VEB), ont été réexposées au $V E B$. Après l'infection, les cellules des lignées Raji et $S 95$, qui ne produisaient pas de virus, ont surtout synthétisé des antigènes précoces (EA) spécifiques du VEB, alors qu'un faible pourcentage de cellules contenait des antigènes des capsides virales (VCA). Dans les cellules Raji, on a observé un parallélisme entre le nombre de cellules productrices de VCA et le pourcentage de cellules synthétisant l'ADN spécifique du virus. Par contre, dans les cellules $S 95$, les cellules synthétisant l'ADN viral étaient au moins dix fois plus nombreuses que les cellules produisant des VCA. L'introduction d'EA dans les cellules Raji dépendait de la dose et était inversement proportionnelle à la croissance cellulaire. L'irradiation du virus par les ultraviolets avant l'infection réduit le pouvoir infectieux. Ce phénomène semble relever d'une cinétique "à un coup". Les cellules Raji, préalablement réexposées au VEB, induisent moins d'EA après la réinfection par le VEB que les cellules témoins Raji qui n'ont pas déjà été exposées au virus. Lors de la réinfection des cellules provenant de dix lignées qui synthétisent spontanément les antigènes spécifiques du VEB, sept lignées se sont avérées réfractaires, alors que trois lignées étaient aussi sensibles que les témoins Raji et $S 95$. Dans trois lignées réfractaires, on a récupéré du virus infectieux dans le milieu de culture avant l'infection.

Ces résultats permettent de formuler les interprétations suivantes: 1) la réponse des cellules lymphoblastoides humaines après la réinfection par le VEB provient du virus infectant et non d'une stimulation des génomes endogènes; 2) les cellules qui synthétisent les EA finissent par mourir; 3) la réexposition au VEB accroit la résistance à la réinfection des cellules survivantes; et 4) les lignées cellulaires produisant $d u$ VEB infectieux sont réfractaires à la réinfection. Les auteurs pensent que la synthèse spontanée du virus infectieux favorise la sélection des cellules résistantes.
\end{abstract}

\section{REFERENCES}

Chang, H. S., Hsieh, M. W., and Blankenship, W., Cell line initiation from cord blood leukocytes treated with viruses, chemicals, and radiation. J. nat. Cancer Inst., 47, 479-483 (1971).

dE Thé, G., Ambrosioni, J. H., Ho, H. C., and KWAN, H. C., Lymphoblastoid transformation and presence of herpes-type viral particles in a Chinese nasopharyngeal tumour cultured in vitro. Nature (Lond.), 221, 770-771 (1969).

Diehl, V., Henle, G., Henle, W., and Kohn, G., Demonstration of herpes group virus in cultures of peripheral leukocytes from patients with infectious mononucleosis. J. Virol., 2, 663-669 (1968).

Durr, F. E., Monroe, J. H., Schmitter, R., Traul, K. A., and Hirshaut, Y., Studies on the infectivity and cytopathology of Epstein-Barr virus in human lymphoblastoid cells. Int. J. Cancer, 6, 436-449 (1970).

EPSTEIN, M. A., Aspects of the EB virus. In: Advances in Cancer Research, 13th ed., p. 383-411, Academic Press, New York and London (1970).
Gerber, P., Activation of Epstein-Barr virus by 5-bromodeoxyuridine in "virus-free" human cells. Proc, nat. Acad. Sci. (Wash.), 69, 83-85 (1972).

Gergely, L., Klein, G., and Ernberg, J., Appearance of Epstein-Barr virus-associated antigens in infected Raji cells. Virology, 45, 10-21 (1971).

Hampar, B., Derge, J. D., Martos, L. M., and WALKER, J. M., Synthesis of Epstein-Barr virus after activation of the viral genome in a "virusnegative" human lymphoblastoid cell (Raji) made resistant to 5-bromodeoxyuridine. Proc. nat. Acad. Sci. (Wash.), 69, 78-82 (1972).

Henle, G., and Henle, W., Immunofluorescence in cells derived from Burkitt's lymphoma. J. Bact, 91, 1248-1256 (1966).

Henle, G., Henle, W., and Klein, G., Demonstration of two distinct components in the early antigen complex of Epstein-Barr virus-infected cells. Int. J. Cancer, 8, 272-282 (1971). 
Henle, G., Henle, W., and Diehl, V., Relation of Burkitt's tumor-associated herpes-type virus to infectious mononucleosis. Proc. nat. Acad. Sci. (Wash.), 59, 94-101 (1968).

Henle, W., Diehl, V., Kohn, G., zur Hausen, H., and Henle, G., Herpes-type virus and chromosome marker in normal leukocytes after growth with irradiated Burkitt cells. Science, 157, 1064-1065 (1967).

Henle, W., Henle, G., Zajac, B. A., Pearson, G., WAUBKE, R., and SCRIBA, M., Differential reactivity of human serums with early antigens induced by Epstein-Barr virus. Science, 169, 188-190 (1970).

Hinuma, Y., Konn, M., Yamaguchi, Y., WudarSKI, D. J., Blakeslee, J. R., and Grace, J. T., Immunofluorescence and herpes-type virus particles in the P3HR-1 Burkitt lymphoma cell line. J. Virol., 1, 1045-1051 (1967).

Horosciewicz, J. S., Dunkel, V. C., Avilla, L. and GraCE, J. T., EB virus infection and propagation in human haematopoetic cells. In: R. M. Dutcher (ed.), Comparative leukemia research, 799, p. 722-738, S. Karger, Basel (1970).

KLEIN, G., Immunological aspects of Burkitt's lymphoma. In: Advances in Immunology, Vol. 14, p. 187, Academic Press, New York and London (1972).

Maurer, B. A., Imamura, T., and Wilbert, S. M., Incidence of EB-virus-containing cells in primary and secondary clones of several Burkitt lymphoma cell lines. Cancer Res., 30, 2870-2875 (1970).

Miller, M. H., Stitr, D., and Miller, G., EpsteinBarr viral antigen in single cell clones of two haematopoetic lines. J. Virol., 6, 699-701 (1970).

Niederman, J. C., McCollum, R. W., Henle, G., and HeNLE, W., Infectious mononucleosis: clinical manifestations in relation to EB virus antibodies. J. Amer. med. Ass., 203, 205-209 (1968).
Nilsson, K., Klein, G., Henle, W., and Henle, G., The establishment of lymphoblastoid lines from adult and fetal human lymphoid tissue and its dependence on EBV. Int. J. Cancer, 8, 443-450 (1971).

Nonoyama, M., and Pagano, J. S., Complementary RNA specific to the DNA of the Epstein-Barr virus: detection of EB viral genome in nonproductive cells. Nature New Biol., 233, 103-105 (1971).

Pearson, G., Dewey, F., Klein, G., Henle, G., and HENLE, W., Relationship between neutralization of Epstein-Barr virus and antibodies to cell-membrane antigens induced by the virus. J. nat. Cancer Inst., 45, 989-995 (1970).

Pope, J. H., Horne, M. K., and ScotT, W., Transformation of foetal human leukocytes in vitro by filtrates of a human leukaemic cell line containing herpes-like virus. Int. J. Cancer, 3, 857-866 (1968).

Pulvertaft, R. J. V., Cytology of Burkitt's tumor (African lymphoma). Lancet, 1, 238-240 (1964).

ZAJAC, B. A., and KoHN, G., Epstein-Barr virus antigens, marker chromosome and interferon production in clones derived from cultured Burkitt tumor cells. J. nat. Cancer Inst., 45, 399-406 (1970).

zUr HAusen, H., Epstein-Barr virus in human tumor cells. Int. Rev. exp. Path., 11, in press (1972).

zur Hausen, H., and Schulte-Holthausen, $H$., Presence of EB virus nucleic acid homology in a "virus-free" line of Burkitt tumour cells. Nature (Lond.), 227, 245-248 (1970).

zur Hausen, H., and Schulte-Holthausen, H., Detection of EB viral genomes in human tumour cells by nucleic acid hybridization. In: P. M. Biggs, G. de Thé, and L. N. Payne, (ed.), Oncogenesis and herpes viruses, Symp. Cambridge, June 1971, IARC, Lyons, 321-325 (1972a).

zur Hausen, H., Diehl, V., Wolf, H., SchulteHolthausen, H., and Schneider, U., Occurrence of EB virus genomes in human lymphoblastoid cell lines. Nature (Lond.), 237, 189-190 (1972b). 